\title{
上眼瞼向き眼振を示した一症例
}

\author{
佐久間 惇・加藤 功・荻野 貞雄 \\ 岡田 智幸・竹山勇
}

\section{A Case Report of Primary Position Upbeat Nystagmus}

\author{
Atsushi Sakuma, Isao Kato, Sadao Ogino, \\ Tomoyuki Okada and Isamu Takeyama \\ (St. Marianna University School of Medicine)
}

\begin{abstract}
A 24-year-old man was admitted because of severe dehydration. He had primary position upbeat nystagmus (PPUN) associated neurological signs of both lower brain stem and cerebellar disorders. ENG examination on the fourth hospital day revealed normal saccadic eye movements, gaze nystagmus in all directions, bilateral decrease of slow phase OKN velocities from ranges of slow stimulus velocity, and bilateral diminution of caloric nystagmus. ENGs and neurological signs strongly suggested brain stem lesions.
\end{abstract}

Key words: primary position upbeat nystagmus, ENG, lower brain stem

はじめに

上眼瞼向き垂直性自発眼振は, 稀な疾患で臨 床報告も少なく, また, 原因疾患も変性症, 脳 腫瘍, 脳血管障害, 栄養障害, 中毒症など多岐 にわたって掞り, その発生機序, 責任部位につ いてはいまだ一定の見解がない。

今回，私共は第 1 頭位で自発性に出現する上 眼瞼向き垂直性眼振を呈した症例を経験し, ENG による神経耳科学的検討を行ったので, 若干の文献的考察を加えここに報告する.

\section{症例}

症例は24歳男性で，昭和61年12月頃，突然悪 心, 嘔吐が出現. 食欲減退, 飲水及び拱食でき ない状態となった. 1 週間後より眩暈, 歩行障 害が出現, 同年12月22日, 路上で倒れていると ころを発見されて当院救命センターに運ばれ， 即日入院となった。翌23日, 当科診察依頼があ
り，ENG を施行した。家族歴，既往歴には特 記すべきものはなかった。

入院時の現症として, 意識レベルは $\mathrm{I}-3$, る いそう, 全身の脱水症状が強く, 口唇炎, 口角 炎を認めた．神経学的には，咽頭反射低下，右 舌の線維束性攣縮等の下部脳幹障害と, 失調歩 行, 指一指試験拈よび指一鼻試験拙劣, Stewart-Holmes 徵候陽性など小脳失調を認め たが，上下肢筋力低下，病的反射等の錐体路症 状を示唆する所見はなかった，血液検査では白 血球数が $10300 / \mathrm{mm}^{3}$, ヘマトクリット值 47.4 $\%$ と高值を示し，尿検査でも，蛋白 $(+)$, ケ トン体 $(2+)$ と脱水時の所見を呈していた.

入院後は補液等の保存的治療にて, 入院時の 各症状は徐々に改善し, 昭和 62 年 3 月 9 日, 退 院となった。 


\section{ENG の経時的変化}

\section{1. 入院直後の所見}

入院 4 日目に施行した視標追跡検査の結果を 図 1 に示寸. 左から水平方向三角波, 垂直方向 三角波，水平方向矩形波ランダム刺激に対する 急速眼球運動である. 水平方向, 垂直方向とも に, 滑動性眼球運動の障害が認められた，急速 眼球運動では dysmetria と眼球速度の変化は認 められなかった。注視眼振検査では, 右注視時 に右向き注視眼振が認められ，左注視時にも左 向き注視眼振と思われるものが認められたが， 眼振緩徐相速度の減衰性は著明ではなかった。 垂直方向にはいずれの方向注視でも著明な上眼

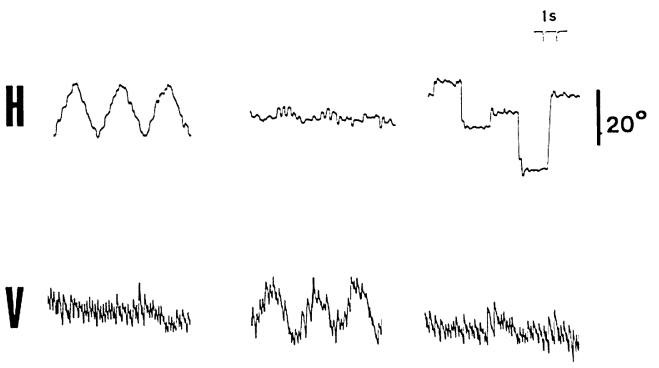

図 1 入院 4 日目に施行した視標追跡検查の結果 左から, 水平方向三角波, 垂直方向三角波, 水平 方向矩形波ランダム刺激を加光, 上段は水平方向, 下段は垂直方向の眼位の変化を表している.
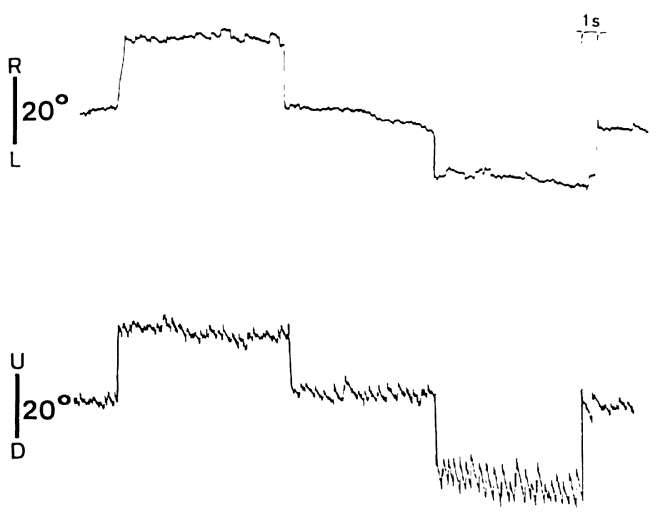

図 2 注視眼振検査の結果 上段は水平方向, 下段は垂直方向の眼位の変化を 表している.いずれの方向注視でる著明な上眼瞼 向き眼振を認めた。
瞼向き眼振を認めた（図 2 ）。視運動性眼振検 查の結果を図 3 に示す．上段は DC 記録の原波 形，下段は時定数を0.03秒でとった微分波形の 緩徐相速度である。回転刺激は $\mathrm{A}, \mathrm{B}$ は左回り $30 \% / \mathrm{S}, 60 \% \mathrm{~S}, \mathrm{C}, \mathrm{D}$ は右回り $30 \% \mathrm{~S}, 60 \% \mathrm{~S}$ で行った，A，B，C，Dの緩徐相速度は，そ れぞれ $10^{\circ} / \mathrm{S}, 15 \% / \mathrm{S}, 17^{\circ} / \mathrm{S}, 19^{\circ} / \mathrm{S}$ であり， 左右いずれの視運動刺激によっても緩徐相速度 の上昇は障害されていた。温度性眼振の結果を 図 4 に示す。 $\mathrm{A}$ は左 $16^{\circ} \mathrm{C}, \mathrm{B}$ は右 $16^{\circ} \mathrm{C}$ の冷 水刺激のもので, 眼振の解発は悪く, 矢印にて 固視させても，左右とも固視抑制は認められな かった.
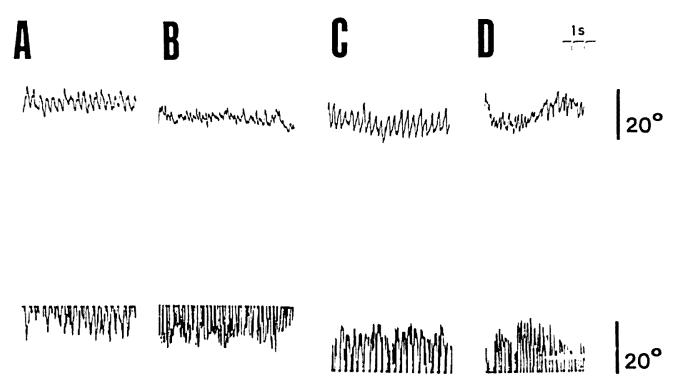

図 3 視運動性眼振検查の結果 上段は DC 記録の原波形，下段はその微分波形 の緩徐相速度で，A，Bは左回り $30 ， 60$ 度，C， Dは右回り 30 度, 60 度の回転刺激を加えている。
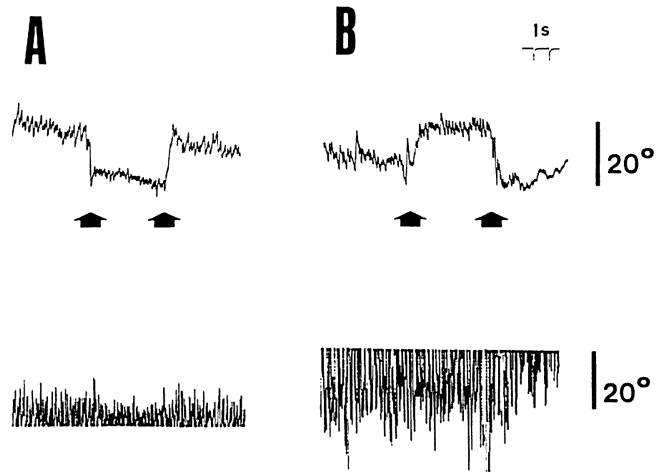

図 4 温度性眼振の結果 $\mathrm{A}$ は左 $16^{\circ} \mathrm{C}, \mathrm{B}$ は右 $16^{\circ} \mathrm{C}$ の冷水刺激である. 矢印は固視のはじめと終わりを示す。 
is

H
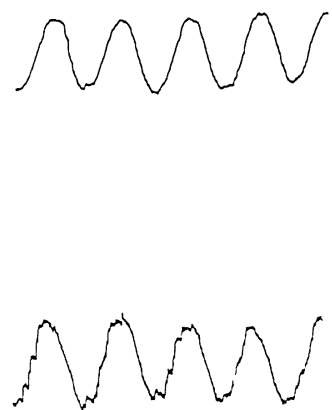

図 5 入院 1 力月後の正弦波を使用した 視標追跡検査の結果

上段は水平方向, 下段は垂直方向の眼位を表す.
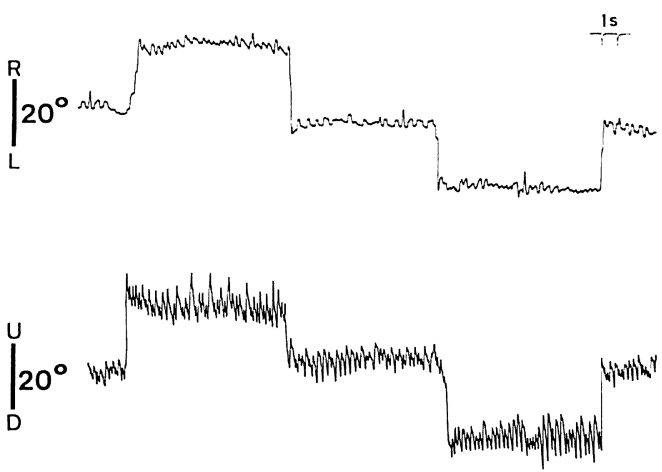

図 6 注視眼振検査の結果
上段は水平方向，下段は垂直方向の眼位を示す.

\section{2. 入院 1 力月後の所見}

図 5 に入院 1 力月後の正弦波刺激を使用した 視標追跡検査の結果を示す. 上段は水平方向, 下段は垂直方向を示し，上眼瞼向きに若干の急 速眼球運動障害が認められるほか，正常に復し ていた。注視眼振検査は，左右方向には注視眼 振は認められず，垂直方向には前回同様の上眼 瞼向き眼振があるものの，頻度，緩徐相速度の 減弱を認めたほか，下方視で上眼瞼向き眼振の 増強を認めた（図 6 ）。図 7 に視運動性眼振検 査の結果を示す． A， B， C，D回転刺激速 度はそれぞれ，右回り $30^{\circ} / \mathrm{S} ， 60^{\circ} / \mathrm{S}$, 左回り $30^{\circ} / \mathrm{S}, 60^{\circ} / \mathrm{S}$ で, 緩徐相速度は各々 $20^{\circ} / \mathrm{S}, 25^{\circ} / \mathrm{S}$, $22 \%$ S， $27 \%$ S であった。左右いずれの刺激で も緩徐相速度は上昇しており，右向きに若干の 障害を認めた程度になっている（図 7 ）。1 $16^{\circ} \mathrm{C}$ の冷水刺激による温度性眼振で矢印にて固視さ せると，緩徐相速度は右 $65 \%$, 左 $60 \%$ の抑制が みられた（図 8)。

\section{考察}

垂直性眼振のらち下眼瞼向き眼振は遭遇する 機会も多く，過去の報告から Arnold-Chiari 奇 形や偏平頭蓋など後頭蓋窩の疾患や，替髄变性 症に観察されることが知られている.

しかし，上眼瞼向き垂直性眼振は，その責任 部位や病態生理に関しては，いまだ混沌として いるのが現状で，動物実験や臨床例をもとに多
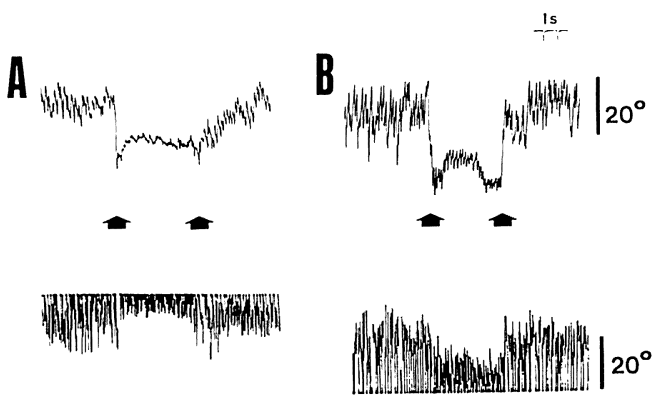

図 8 温度性眼振の結果

図 7 視運動性眼振検查の結果 上段は DC 記録の原波形, 下段はその微分波形 の緩徐相速度で，A，B山右回り $30 ， 60$ 度，C， Dは左回り30度，60度の回転刺激を加えている。

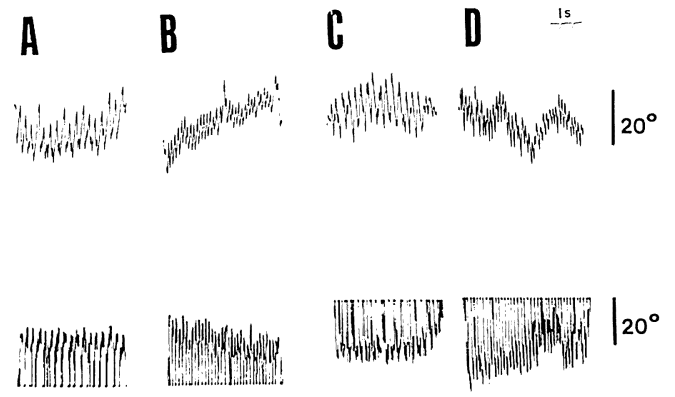


くの議論がなされてきた．上眼瞼向き眼振を呈 した症例の原因疾患をみていると，馬塲ら1)の 報告では慢性アルコール中毒や栄養障害の比率 は43例中 8 例にみられ，ビタミン吸収障害との 関係も否定できない。

上眼瞼向き眼球運動の責任部位については,

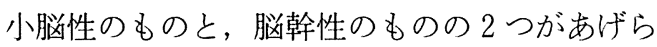
れている。ネコを用いた基礎実験では Spiegel ら²)は小脳後葉正中部を, Cohen 53) は片側山 頂, 両側歯状核, 係蹄小葉を, Sato $5^{4) 5)}$ は片 葉吻側帯としている. Troost 56)は臨床例から 責任部位は下オリーブ核とした。しかし，五十 嵐らては，ネコの実験で下オリーブ核に限局し た障害では上眼瞼向き眼振は発現せず，第 4 脳 室まで障害が及んだときにだけ認められたと述 べている。また，原田ら ${ }^{8)}$ はネコの両側舌下神 経前位核の破壊実験で上眼瞼向き眼振を示した 例もあるとしている。

上眼瞼向き垂直性自発眼振の発生機序に関し て，馬塲ら1は 2 つの説があるとしている。一 つめは Zee ${ }^{9)}$, Gilman ${ }^{10)}$ らが提案した pursuit defect nystagmus とする説で，これは vertical smooth pursuit $の$ tonic imbalance によってお こるとされている．特に Gilman は，彼の論文 の中で，下オリーブ核，小脳正中部，舌下神経 前位核が垂直性眼球運動の経路であり，この部 位の障害で垂直性眼振が誘発されると述べてい

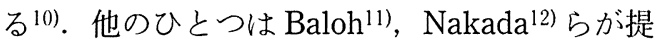
案した central vestibular nystagmus とする説 で，垂直性前庭眼反射の経路の tonic imbalance によっておこるとされている。

臨床例で，加藤ら ${ }^{13)}$ は舌右偏位，同側の線 維束性攣縮を認めた下部脳幹の出血と思われる 症例で，上眼瞼向き眼振を認めたことから舌下 神経前位核が垂直性眼球運動のトーヌスに関連

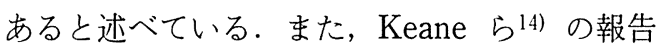
では，延髄背側部内側の梗塞で死亡した 2 症例 の剖検に上眼瞼向き眼振を認めたことより，舌 下神経前位核は垂直性眼球運動に大きく関与し ているとしている，以上述べたように垂直性眼
振の原因は小脳と脳幹とされてきたが，第 4 脳 室の直下にある舌下神経前位核が垂直性眼球運 動の調節部位と仮定するなら，下部脳幹そのも のの出血, 梗塞, 変性や第 4 脳室及び小脳の腫 瘍, 出血, 奇形, 浮腫などから下部脳幹の間接 的圧迫による舌下神経前位核障害で垂直性眼振 が出現することが説明できる.

今回の症例の ENG の結果を検討してみると， 責任病巣について以下のことがいえる. 視標追 跡検查の結果，急速眼球運動についてみると dysmetria が認められなかったことから小脳障 害は考学にくい。また, 注視眼振検査では, 水 平方向の, しかも減衰傾向のない眼振が認めら れたが，岡田ら ${ }^{15)}$ は発生機序について脳幹と 小脳との情報連絡の途絶によりおこると説明し ており, 小脳, 脳幹いずれの障害でも起こり得 ると考えられる. 視運動性眼振検査はネコやサ ルの実験から脳幹障害と小脳障害との鑑別が可 能と考兄られており ${ }^{15)}$, 今回の症例のように低 速度から障害されていることは脳幹障害を示唆 している．温度眼振検査では眼振の解発が悪く， 固視抑制は認められなかったことから，脳幹お よび小脳片葉障害が考えられる。

神経症候学的に舌の線維束性攣縮と咽頭反射 の低下が認められたこと, ENG の結果, 急速 眼球運動で dysmetria を認めなかったこと, 減 衰しない水平方向の注視眼振を認めたこと, 視 運動性眼振が低速から両側性に障害されたこと, 温度性眼振の解発が悪かったことなどから, 責 任病巣は舌下神経前位核を含めた下部脳幹であ ると考察した。

\section{まとめ}

今回，臨床的には脱水，低栄養が引き金とな った小脳脳幹障害と思われる症例で上眼瞼向き 垂直性自発眼振がみられたが，神経耳科学的に 検討すると，1）急速眼球運動でdysmetria を 認めなかった， 2 ) 減衰しない水平方向の注視 眼振を認めた，3）視運動性眼振が低速から両 側性に障害された，4）温度性眼振の解発が悪 かった，などの ENG 所見から，その責任部位 
は加藤, Keane らがいら下部脳幹にあると考 えられた。

\section{参考文献}

1）馬塲完二, 坂田英治, 中沢 宏, 他: Primary position に括将る spontaneous vertical nystagmus の文献的考察と病態生理一upbeat nystagmus, down beat nystagmus, alternating vertical nystagmus の自験例とともに一. 耳鼻臨 床 $79: 193 \sim 212,1986$.

2) Spiegel EA and Scala NP : Vertical nystagmus following lesions of the cerebellar vermis. Arch Ophthamol 26 : 661 669, 1941.

3) Cohen B, Goto $K$, Shanzer $S$, et al : Eye movements induced by electric stimulation of the cerebellar in the alert cat. Exp Neurol $13: 145 \sim 162,1965$.

4) Sato $Y$ and Kawasaki $T$ : Functional localization of the floccular three zones related to eye movement control in cats. Brain Res $290: 25$ $\sim 31,1984$.

5) Sato $Y$, Kawasaki $T$ and Ikarashi $K$ : Afferent projections from the brainstem to the three floccular zones in cats. Brain Res $272: 27 \sim 36$, 1983.

6) Troost BT, Martinez J, Abel LA, et al : Upbeat nystagmus and internuclear ophthalmoplegia with brainstem glioma. Arch Neurol $37: 453 \sim 456,1980$.

7）五十嵐淑晴, 水越鉄理, 細川 智, 他 : 上眼瞼 向き垂直性眼振の発生機序について, Equili- brium Res $37: 68 \sim 72,1978$.

8）原田浩二：上眼瞼向き垂直性眼振の責任部位に ついて. Equilibrium Res $40: 73 \sim 74,1981$.

9) Zee DS, Friendlich AR, Robinson DA, et al : The mechanism of down-beat nystagmus. Arch Neurol 30 : 227 237, 1974.

10) Gilman N, Balof RW and Tomiyama U : Primary position upbeat nystagmus-a clinicopathologic study-. Neurology $27: 294$ $\sim 298,1977$.

11) Baloh RW and Spooner JW : Downbeat nystagmus ; a type of central vestibular nyustagmus. Neurology $31: 304 \sim 310,1981$.

12) Nakada $T$ and Remler MP : Primary position upbeat nystagmus : an other central vestibular nystagmus? J Clin Neuro-Ophthalmol 1 : 185 189, 1981.

13) Kato I, Nakamura T, Watanabe J, et al : Primary position upbeat nystagmus. Arch Neurol 37 : 491 494, 1987.

14) Keane JR and Itabashi $H$ : Upbeat nystagmus : clinicopathologic study of two patients. Neuology 37 : 491 494, 1987.

15）岡田智幸, 竹山 勇, 加藤 功, 他: 脳圧穴進 症状を伴わない第 4 脳室上衣腫例一神経耳科学 的検討一. Equilibrium Res 48: 151 160, 1989.

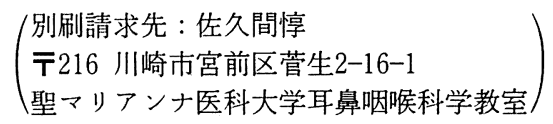

